\title{
Discursos memoriais, uma proposta de investigação histórica
}

\author{
Memorial discourses, a proposal for historical research \\ Discursos memorizados, una propuesta de investigación histórica
}

GuilhermeAmorim de Carvalho

\section{Resumo}

O presente artigo apresenta uma síntese de reflexões teórico-metodológicas e procedimentos de pesquisa em relação à análise histórica de discursos memorialistas, buscando reconhecer e reconstruir sua dimensão política, assim como as estratégias retóricas utilizadas pelos autores para conferir uma representação ideal da ordem político-social, a partir da qual o seu público receptor poderia reconhecer seus papéis sociais.

Palavras-chave: Análise do discurso. Monarquias Ibéricas. Representação do Poder.
O presente artigo ocupa-se em apresentar determinados princípios teóricos e metodológicos para a análise histórica de discursos voltados para a composição de memórias acerca da vida e morte de homens notáveis. No entanto, não se pretende propor uma teoria definitiva para o estudo de discursos em História, mas apresentar determinadas reflexões epistemológicas acerca do tema, a partir de um exemplo específico: os discursos memoriais das monarquias ibéricas seiscentistas.

Primeiramente, ocupamo-nos em delinear o que chamamos aqui de "discursos memoriais". No que diz respeito à teoria literária, tratam-se de composições de natureza retórica, inseridas no gênero demonstrativo,

\footnotetext{
Doutor em História pela Universidade Federal de Ouro Preto (2017), com período sanduíche na Universidade de Évora. E-mail: guilhermejawa@hotmail.com

Recebido em 26/4/2018 - Aprovado em 13/6/2018 http://dx.doi.org/10.5335/hdtv.18n.3.8598
} 
ou epidíctico. Isto é, sua motivação principal é o elogio ou vitupério de um personagem que, de alguma forma, obteve destaque perante o restante da população.

Como afirma Chaïm Perelman e Lucie Olbrechts-Tyteca (1996), Aristóteles e os teóricos inspirados por ele incluíam o gênero epidíctico ao lado dos gêneros oratório, deliberativo e judiciário. Para esses pensadores, ao contrário dos debates deliberativos (ou políticos) e judiciários, nos quais os contendedores buscavam obter a adesão do auditório acerca de matérias controversas, relativas ao desfecho de um processo ou de uma ação por empreender, os discursos epidícticos se limitavam a apresentar premissas as quais ninguém se opunha, acerca de matérias evidentes, a partir das quais não se esperava nenhuma consequência prática. Nessa perspectiva, os membros do auditório representavam o papel de espectadores, cabendo a eles apenas o aplauso ou a reprovação da obra.

Para Aristóteles, o gênero epidíctico, por ter como finalidade o elogio ou a censura, ocupava-se com o belo (bom) e o feio (mau), isto é, tratava do reconhecimento e da afirmação de valores. Os teóricos do discurso pós-aristotélicos, ao não se aterem à finalidade edificante dos discursos epidícticos, tampouco à sua eficácia quanto à adesão do auditório, resumiram os valores morais, religiosos e políticos apresentados nos discursos à ideia de valor estético do discurso como um todo. Isso resultou na concepção de que os discursos epidícticos não possuíam um papel importante na argumentação e, consequentemente, para a adesão do auditório a uma tomada de decisão ou em- preendimento de uma ação (PERELMAN; OLBRECHTS-TYTECA, 1996).

No entanto, isso parte de uma concepção errônea acerca do discurso epidíctico e dos seus efeitos argumentativos. Nesse tipo de discurso, não se pretende convencer o auditório acerca de verdades especulativas, mas intensificar a adesão deste a valores efetivos. Assim, o orador busca criar um consenso em torno de valores reconhecidos pelo público receptor, por meio de um instrumental retórico que lhe permite ampliar e fortalecer tais valores. Nesse sentido, a eficácia do discurso deve ser julgada a partir de suas finalidades, nesse caso, a adesão a valores reconhecidos como legítimos, visando a ações que tais valores propõem (PERELMAN; OLBRECHTS-TYTECA, 1996).

No caso dos discursos memoriais do Antigo Regime ibérico, que se inserem no gênero epidíctico, esses não tinham apenas a finalidade de elogiar ou vituperar, mas também uma finalidade deliberativa, pois estavam orientados para ensinar, orientar, aconselhar, exortar, advertir, repreender; em suma, para retificar ou modificar a conduta do público receptor, tendo em vista a execução de determinadas ações dentro dos valores da nobreza e da religião cristã (URREJOLA, 2012).

Além das finalidades de elogiar, vituperar e mover à ação, os discursos memoriais também tinham características do gênero judicial, haja vista a utilização de terminologias judiciais em conjunto com a tradição teológica e política, destinadas a fomentar o ajustamento do público receptor à ordem social, assim como o temor a Deus e o incentivo a uma conduta cristã. Esse vocabulário 
judicial, baseado em culpas, juízos, castigos e redenções constituía a essência da religião Católica, cuja teologia estava marcada pela ideia do Juízo Final, mas, também, da política, pois os comportamentos políticos da nobreza deviam estar ajustados à vontade de Deus, o Supremo Juiz (URREJOLA, 2012).

Dessa maneira, os autores dos discursos memoriais censuravam aqueles que se desviavam da lei divina, da mesma maneira que acusavam os nobres que procurassem seu próprio interesse em vez do bem-comum da monarquia, ao passo que defendiam os bons cristãos e os governantes que consideravam justos. Assim, pode-se concluir que os discursos aos quais denominamos memoriais, combinam características dos três grandes gêneros da oratória clássica, o epidíctico, o deliberativo e o judiciário.

Observando tais apontamentos, pode-se citar como exemplo de tais discursos, diversas composições literárias, como crônicas, panegíricos, sermões, orações e toda forma de narrativa dedicada a elogiar as virtudes ou a censurar os vícios em determinados aspectos da vida e morte de homens que desempenharam algum papel relevante dentro de uma organização político-social, com o objetivo tanto de instruir o público receptor aos bons costumes e virtudes, segundo a moral cristã, como de convocá-lo ao melhor serviço da Igreja e da Coroa.

Em suma, podemos afirmar que os discursos memoriais, de forma genérica, constituem um conjunto de narrativas nas quais os autores compunham, retoricamente, um campo de ação voltado para a legitimação e confirmação de preceitos morais e práticos considerados necessários para o bom exercí- cio de ofícios de ordem superior, fossem eles políticos, militares ou administrativos.

À vista disso, os chamados discursos memoriais, mais do que um gênero retórico-poético em particular, eram práticas discursivas formalizadas de variadas formas, todas partícipes da instituição retórica (HANSEN, 2013). Como tais, elas pressupunham maneiras específicas de se compor memórias de homens notáveis, bem como padrões normativos que as regulavam e legitimavam, conforme o decoro das ocasiões. Isso permite relacioná-las, independentemente de sua composição estrutural, a partir da recorrência de determinados elementos discursivos, tais como conceitos, metáforas, representações e estratégias de persuasão. Em princípio, tais repetições podem ser sintomas de um contexto histórico concreto, com todas suas combinações de circunstâncias e mudanças sociopolíticas (RAMİREZ, 2009).

Podemos também pensar essa recorrência de elementos retóricos como "preceitos técnicos objetivamente partilhados". Isto é, as estratégias argumentativas estavam condicionadas segundo um repertório prévio de padrões referenciais, objetivados em imagens de representação e dispostos em uma lógica dialética. Essas representações eram recombinadas de discurso a discurso, e adequadas conforme o tipo de texto. Levando isso em consideração, os discursos não devem ser interpretados apenas em seu nível expressivo ou subjetivo, mas, também, em relação às suas estratégias discursivas (HANSEN, 2008).

Embora haja diferenças temáticas e estruturais entre uma crônica e um sermão fú- 
nebre, ambos têm uma mesma e fundamental utilidade, que é a de manter presentes os feitos dos grandes homens, e a partir desses, oferecer modelos de conduta e preceitos morais para o público receptor, incitando-o a agir segundo tal modelo prescritivo, ou seja, a realizar grandes obras e exercitar virtudes, para ser igualmente digno de memória.

Portanto, apesar das diferenças estruturais que possam existir entre um sermão e uma crônica, é possível dizer que ambas as espécies de composição retórica apresentam uma unidade geral de sentido que nos permite relacioná-las. Tal unidade de sentido consiste em compor uma memória acerca de uma grande personalidade, para que essa sirva de modelo às gerações futuras no que diz respeito ao agir político, a partir de um princípio ordenador moral que fundamenta e legitima tal sentido.

Colocando em outras palavras, não obstante a heterogeneidade composicional, todas essas obras buscam transmitir um exemplo relativo ao exercício de um cargo ou posição de importância dentro da organização político-social, o que resulta na recorrência de repertórios retóricos e estratégias discursivas bastante semelhantes, partilhados entre os vários tipos de discurso.

\section{0 princípio metafísico dos discursos}

O que chamamos "princípio ordenador moral" era definido por uma "teologia política", que ocupava lugar central na mentalidade da época, e vinculava política e religião (FERREIRA, 2007), a partir do mesmo imaginário acerca da sociedade e do poder, segundo o qual a organização político-social tinha como modelo a hierarquia celestial, que conformava a ordem temporal à metafísica, embora essa primeira devesse ser constantemente retificada pelo ajuste moral, devido ao seu caráter imperfeito. Dessa maneira, é possível afirmar que assim como os tratados morais e espelhos de príncipe, os discursos memoriais eram, muito além de mera coletânea de memórias, discursos morais, mesmo que dispostos em forma de narrativa.

A ideia de que a monarquia temporal era um reflexo imperfeito da hierarquia celestial, aparece no famoso tratado de Sebastião César de Meneses ${ }^{1}$, intitulado Summa politica. Offerecida ao Principe D. Theodosio nosso Senhor, impresso em 1649. O autor, ao discorrer acerca de como deve ser a educação dos príncipes, afirma que:

A primeira lição deve ser dos feitos, \& proezas de seus progenitores, \& vassallos, com noticias de suas ascendencias, \& costumes: pera dar a cada hu o lugar, que lhe compete: porque ainda que a benevolencia deve ser commum pera todos os vassallos; a estimação he justo que tenha seus graos pera o tratamento: pois atè na Corte Celestial se distinguem, \& aventajão as hyerarquias (MENESES, 1649, p. 27).

Seguindo por essa lógica, é possível perceber que os discursos memoriais eram ordenados a partir de um princípio metafísico, que compreendia a ordem celestial e o próprio criador. Nas narrativas dos discursos, tal princípio era o fundamento de articulação e justificativa de duas instâncias: por um lado a memorialista, que se comprometia a manter presentes os feitos dos grandes homens, representados como marcos na ordem de criação, e por outro a moralista, 
que oferecia modelos de conduta e preceitos morais e religiosos para o público receptor (FRANÇA, 2010). Tal característica é o que diferencia os discursos memoriais de outros tipos de texto que, ainda que digam respeito à memória, possuem princípios ordenadores diferentes, como é o caso dos anais, capítulo de Corte, memoriais de requerimento, atas diplomáticas e tantos outros.

Resta-nos ainda conceituar o que entendemos por "discurso". Primeiramente, consideramos que não há uma correspondência direta, imediata e necessária entre texto e discurso. Não pretendo adentrar em uma discussão mais detalhada acerca desse tema, creio que para os objetivos propostos, seja o suficiente dizer que um texto se torna discurso a partir do momento em que se vincula a uma determinada dimensão extratextual, dentro e a partir da qual ele adquire, ou produz sentido.

Dessa forma, é possível dizer que em um discurso não há um sentido natural, atemporal ou universal, uma vez que sua condição exige que ele se relacione com elementos que possibilitaram sua produção, isto é, um discurso jamais se autonomiza completamente em relação a suas condições e processos de produção formal e de sentido, ainda que as respostas possíveis do público receptor ao discurso possam ser de aceitação ou rejeição.

Isso é dizer que um texto se torna discurso a partir do momento em que ele se relaciona a uma enunciação concreta, ou seja, quando ele se materializa em forma de enunciado, deixando de ser uma unidade abstrata e fechada em si mesmo, para conectar-se a algum elemento (ou alguns elementos) que permita que ele se vincule à situação na qual ele foi produzido, seja essa um emissor, um destinatário, um local, uma data, uma instituição, uma intenção, uma tradição, um sistema de representação (URREJOLA, 2012), enfim, a uma série de elementos que lhe conceda uma dimensão extratextual ou situação concreta.

Nesse sentido, utilizando o sermão fúnebre como exemplo ilustrativo, diríamos que se trata de um discurso cujo texto diz respeito a um orador (emissor), um destinatário (ouvintes ou leitores), uma intenção ou propósito (homenagear o defunto e ensinar o caminho da salvação), um local (o púlpito), uma data (dia do funeral) uma instituição (a Igreja), uma tradição (a tradição cristã), e assim por diante.

Cada um dos elementos citados confere uma realidade extratextual ao sermão, que continuará subsistindo, mesmo após ele ter sido escrito, editado, impresso e difundido em formato de livro. Isto é, independentemente da circunstância em que se possa vir a fazer uso do discurso (oração no púlpito de uma igreja, em uma data comemorativa, em um funeral, ou mesmo na leitura individual silenciosa), ao nosso entender, ele estará sempre subordinado aos elementos extratextuais que deram origem a sua produção, e que não cessarão de conferir-lhe sentido, ainda que esse esteja sujeito a determinadas alterações, em decorrência das especificidades de cada circunstância. Ou seja, um discurso está sempre subordinado à sua condição sincrônica de produção, embora, isso não queira dizer que não existam tensões acerca da validade dos sentidos que lhes são conferidos pelo público receptor. 
Para melhor esclarecimento daquilo que foi afirmado acima, pode ser citado como exemplo o seguinte: um sermão fúnebre lido no exato dia das exéquias reais terá o propósito de homenagear e despedir-se do falecido rei e, de outro modo, o mesmo sermão proferido no aniversário das referidas exéquias reais terá um propósito que vai além do original, o qual seria o de perpetuar a memória do rei. Entretanto, em ambas as circunstâncias, o enunciado original continua o mesmo: as exéquias reais.

Ao diferenciar texto de discurso, não pretendemos negar a relevância do texto e de suas categorias formais como critério de análise, mas assinalar a importância da perspectiva discursiva para a pesquisa em História.

Retomando o que foi colocado anteriormente, os discursos memoriais são discursos que partem da moralidade e exemplaridade de uma pessoa, seja compondo uma unidade épica por meio de sua trajetória (crônica), ou ainda enumerando suas virtudes (sermão), no intuito de confirmar uma generalidade, no caso, o modelo de organização político-social existente. Dessa maneira, o autor do texto no qual o discurso ocorre deixava transparecer a autoridade moral do homenageado, confirmando sua conduta como legado organizacional para todos aqueles que futuramente viessem a ocupar o mesmo cargo, ou outro semelhante.

Portanto, por meio das trajetórias individuais exemplares, acontecimentos notáveis narrados nos textos, e exposição das virtudes pontuais que compunham a figura modelar do homenageado, os discursos memoriais ofereciam, mesmo que indiretamen- te, um conhecimento válido das estruturas político-sociais e de suas práxis formais e informais, as quais conferiam sentido à ação política e que possibilitavam ao público receptor um cálculo aproximado de seus respectivos efeitos.

Consequentemente, ao oferecer um saber geral acerca do funcionamento do ordenamento político-social, os discursos memoriais também contribuíam para instituir e reafirmar as exigências concretas que advinham de uma situação política prática, pois aquilo que é moralmente válido, somente é reconhecido inteiramente mediante o surgimento de uma situação que demande uma ação concreta, ou como defende Gadamer (1998, p. 466): "aquele que atua deve ver a situação concreta à luz do que se exige dele em geral". Desse modo, o conhecimento acerca do ordenamento social e das jurisdições de cada esfera de poder, contido nos discursos memoriais, indicava quais seriam os comportamentos e as atitudes moralmente aceitos a serem adotados pela nobreza, a partir das experiências do homenageado narradas em forma de memória.

Considerando que tais discursos partem do singular para o geral, ou do factual para o universal, ou seja, de uma trajetória pessoal para a moral que a informa, as narrativas exerciam, além das funções supracitadas, a de controlar as novidades impostas à ação política pelo quotidiano, por meio da autoridade da memória e do exemplo construídos no discurso enquanto passado, a partir de representações teológico-políticas conhecidas e partilhadas por toda a sociedade, conformando-as ao modelo de ordenação político-social instituído, para que essas 
não assumissem um caráter inovador, mas conformador.

De acordo com Maravall (1997), no século XVII, a experiência vai ocupando, cada vez mais, um papel de centralidade dentro daquilo que ele chama "cultura do barroco". A experiência particular adquire maior autonomia em relação às forças sobrenaturais e o testemunho pessoal passa a ser um importante critério para a organização mental e representação da relação entre o homem e a organização político-social. A partir disso, o homem "barroco" concebia a experiência de duas formas: primeiramente, ele reconhecia a existência de fatos singulares, cujos sentidos eram evidentes por si próprios, em segundo lugar, ele também reconhecia que para além desse sentido particular e autoevidente, existiam outros sentidos concorrentes, conferidos pela religião, pela tradição e pela moral, tais como o modelo de organização político-social e suas representações, o que permitia a sociedade "barroca" relacionar experiências singulares a certos modelos organizacionais generalizantes.

Seguindo por essa lógica, acreditamos que essa dupla concepção "barroca" da experiência projetada para as trajetórias singulares dos nobres permitia aos autores dos discursos conformarem as novidades vividas pelos homenageados à organização político-social instituída, inscrevendo-as, retoricamente, na representação ideal e pré-validada do grupo social e dos valores a ele relativos, conferindo legitimidade às ações narradas, para que essas pudessem se tornar lições exemplares para o público receptor.

Do século XVI ao século XVIII, a representação, enquanto modo de "dar a conhecer um objeto ausente através de uma imagem presente, capaz de fazer figurar na memória o objeto tal como ele é" (ANDRADE, 2008, p. 29), era a base fundamental que regia as normas de conduta e identidades sociais. Assim, as representações da ordem social e das suas esferas de poder político compunham modelos retóricos aos quais os discursos memoriais deveriam se conformar. Portanto, o imaginário acerca da sociedade e dos seus estamentos, enquanto princípio de compreensão que os homens possuíam de si e da organização hierárquica da sociedade, constituía o principal critério de autoridade do discurso memorial.

No entanto, para que as ações dos homenageados fossem legitimadas, além da autoridade da representação reconhecida do ordenamento político-social e dos valores correspondentes a cada esfera jurisdicional dentro deste, o discurso memorial necessitava de outras evocações de autoridade. Primeiramente, como ficou entendido anteriormente, esses discursos possuíam um princípio ordenador moral definido pela religião.

Esse princípio estava orientado para a finalidade última da criação, que era a salvação da alma e a contemplação da Verdade Divina. Nesse sentido, em uma perspectiva global da criação, toda ação humana estava voltada para alcançar esse fim (MASSIMI, 2005). Desse modo, os discursos memoriais deveriam demonstrar que as ações do homenageado estavam em consonância com o fim supremo da sua existência para, desta forma, torná-los exemplos autorizados para a instrução do público receptor. 
Assim, tratava-se de demonstrar que o nobre homenageado no discurso memorial utilizou seu livre-arbítrio em consonância com a ordem providencial do cosmos, ou a Providência Divina, pois só era considerado realmente livre, aquele cuja vontade se coadunasse com a busca do bem supremo, identificado como a salvação (MASSIMI, 2005). Desse modo, ao demonstrar que as ações do personagem do discurso estavam voltadas para a finalidade última da criação, que perpassava também a ordem natural e, portanto, estava ligada à finalidade mundana da trajetória do nobre, que era a de agir em prol do bem comum, o autor evoca uma autoridade sobrenatural, que legitimava as ações narradas no discurso.

Em segundo lugar, o discurso evocava a autoridade do próprio notável, que por possuir o estatuto social de nobre, era considerado um modelo moral para aqueles que se encontravam nas esferas mais baixas da ordem social, assim como um modelo de inspiração para seus pares. Haja vista que a trajetória do nobre em questão fora digna de memória, pressupõe-se que ele já dispunha de prestígio público, advindo do ajuste das suas ações ao cargo por ele ocupado, não somente no âmbito institucional, mas também no simbólico, isto é, o homenageado, para alcançar a autoridade que legitimasse seus feitos, deveria ser capaz de representar sua honra por meio da demonstração pública de virtudes inerentes à condição de nobre (ANDRADE, 2008), tais como a prudência, a lealdade, a fé e a caridade. Dessa maneira, as ações narradas nos discursos memoriais estavam autorizadas pela reputação e pela honra do homenageado.
No entanto, deve-se considerar que os autores dos discursos memoriais não compunham sua obra a partir de padrões iluministas, haja vista a ausência de autonomia autoral no âmbito dos letrados do mundo ibérico no século XVII. Como aponta Hansen, isso significava que não havia uma originalidade autônoma e subjetiva na invenção geral do discurso. $\mathrm{O}$ processo criativo do autor seiscentista estava regrado por usos autorizados de temas, representações, efeitos e estratégias retóricas, partilhadas coletivamente pela comunidade letrada, os quais eram utilizados de acordo com a "memória social de seus bons usos". Ademais, os letrados também estavam subordinados às instâncias hierárquicas superiores, como ordens, conselhos, universidades e, portanto, deviam observar quais eram os fins de tais instâncias. Nesse sentido, a atividade do autor era definida pelas categorias de pertença ao corpo social e subordinada ao bem comum desse (HANSEN, 2008).

Dessa forma, a autoridade do autor provinha do seu conhecimento acerca do referencial discursivo que lhe era possível utilizar, como os modelos retóricos clássicos, "preceitos doutrinários aristotélicos, neoplatônicos, patrísticos, escolásticos e neoescolásticos da teologia-política ibérica", dos quais ele se apropriava e os adaptava nos discursos, por meio de sua intervenção particular; e segundo a proposta das instituições às quais ele estava subordinado, assim como das circunstâncias locais e temporais em que ele estava inscrito (HANSEN, 2008, p. 197).

Entretanto, apesar desse elenco pré-definido pela memória dos usos autoriza- 
dos das representações, recursos retóricos e técnicos, o processo criativo dos autores ibéricos seiscentistas não era engessado. A imaginação era considerada como a manifestação da Luz de Deus na consciência do letrado, a partir da qual o propósito divino revelava e ordenava as imagens internas, que tornavam inteligíveis as abstrações de ações concretas e objetos materiais (HANSEN, 2008).

Nessa concepção, a imaginação era a parte do intelecto que elaborava as representações de objetos ausentes, a partir das imagens suscitadas pela iluminação divina, selecionando os temas e as representações adequadas ao tipo e à intenção do discurso proposto. Tal iluminação divina permitia estabelecer relações extraordinárias entre objetos e conceitos. Assim, as representações retóricas, como as metáforas, eram concebidas como efeitos da Luz de Deus na consciência do autor, que ao revelar abstratamente aspectos inteligíveis de uma matéria, evidenciava a presença divina nesse processo criativo (HANSEN, 2008).

As imagens metafóricas, elaboradas pelos autores dos discursos, eram consideradas representações exteriorizadas de conceitos que participavam da iluminação de Deus. Nessa perspectiva, haja vista que todas as imagens assim criadas eram análogas às contidas na Luz Divina, elas também se aproximavam entre si, pois eram efeitos da mesma "Causa luminosa". Desse modo, era possível aos autores aproximar imagens e conceitos bastante distantes, o que se denominava agudeza. Quanto maior a agudeza, mais se evidenciava a manifestação da Luz Divina na criação do discurso (HANSEN, 2008).
Com a valorização da imaginação e da agudeza enquanto eixos centrais na criação dos discursos, os autores contavam com várias possibilidades de arranjos de representações e recursos retóricos, ainda que ordenados a partir de modelos pré-definidos. Pode-se dizer, metaforicamente, que os autores dispunham seus textos como um "xadrez de palavras", no qual a agudeza correspondia aos "lances" efetuados, os quais combinavam argumentos e representações, enquanto o engenho era o conhecimento que o autor possuía acerca das regras que delimitavam as combinações de palavras, em outras palavras, o engenho era a capacidade técnica do autor aplicada à sua agudeza (HANSEN, 2008).

Retomando a questão da evocação de autoridades nos discursos memoriais, gostaríamos de ressaltar que, segundo Gadamer, a autoridade não se fundamenta, essencialmente, em um ato irracional de submissão, ou obediência cega por parte do sujeito, mas em uma atitude de conhecimento e reconhecimento. Atribui-se autoridade a uma pessoa, a partir do momento em que se reconhece que essa encontra-se em um patamar superior de entendimento e que, portanto, seu juízo apresenta primazia sobre o dos demais. Disso depreende-se que a autoridade, antes de outorgada, é adquirida. Ela parte de uma ação de reconhecimento, que faz com que os sujeitos reconheçam seus limites e confiram a outro uma perspectiva mais apropriada (GADAMER, 1998).

Assim sendo, não devemos negar a participação do público receptor na legitimação/autorização dos discursos memoriais. Nas monarquias ibéricas do século 
XVII, o público receptor assumia o papel de juiz da eficácia da construção retórica da obra, ou seja, do efeito produzido pelas representações teológico-políticas apresentadas na narrativa. Sendo assim, o público era considerado como conhecedor dos preceitos de coerência que regravam a composição dos discursos, conformando aquilo que poderia ser acrescentado ou retirado da sua estrutura formal. Consequentemente, os juízos emitidos pela recepção da obra também eram normativos, haja vista que cada grupo da totalidade do corpo social se reconhecia a partir das representações que os discursos memoriais faziam acerca de suas posições na ordem hierárquica da sociedade (HANSEN, 2008).

Vale ressaltar que não se tratava de uma "opinião pública" dotada de autonomia política ou crítica, mas da identificação e ratificação de posições hierárquicas, assim como do reconhecimento dos privilégios e deveres relativos aos diversos grupos sociais, por meio de suas representações (HANSEN, 2008).

Para completar esse quadro de legitimação do discurso, é necessário apontar que os feitos do homenageado deveriam estar vinculados, de alguma forma, a um passado imemorial, isto é, àquilo que sempre foi e deveria continuar sendo. A trajetória do nobre se ligava à outra mais ampla, a do reino, que por sua vez, inseria-se na história das "intervenções temporais da Providência Divina". Nesse sentido, por um lado, o louvor aos feitos e virtudes do homenageado exaltavam o passado, por outro, não deixavam de prescrever o presente, pois constituíam modelos exemplares de conduta (FERREI-
RA, 2007). Ademais, pela expectativa de que os nobres agiriam de acordo com os exemplos narrados nos discursos, para que suas trajetórias também fossem dignas de memória, os discursos buscavam edificar o futuro (FRANÇA, 2010).

Contudo, a verdade moral superior transmitida pelos discursos memoriais não assumia, necessariamente, um caráter absoluto ou dogmático, visto que ela decorria de experiências práticas. A seleção daquilo que poderia ou não ser memoriável dependia das disputas de interesse entre grupos político-sociais, assim como dos limites impostos pela compreensão e aceitação do público receptor. Diacronicamente, de um discurso memorial para outro, ocorria uma atualização dessas experiências, pois, se era a partir delas que se aprendiam as lições do passado, presumia-se que os discursos devessem possuir a faculdade de narrar as novas experiências do presente e, com base nelas, formular um novo aprendizado (KOSELLECK, 2006), o que oferecia novas oportunidades de afirmação dos interesses de pessoas e grupos conflitantes.

Isto é, diante de uma situação concreta da vida de um nobre a qual deve narrar, o autor de um discurso memorial se via obrigado a fazer certas "concessões" em relação aos fundamentos morais tradicionais que envolviam tal situação, não por um desvio, ou desrespeito à moral, mas por encontrar o que moralmente melhor se ajustava à situação, portanto, era necessário que o autor possuísse o conhecimento que o "autorizasse" a fazer esse tipo de formulação de novos aprendizados (GADAMER, 1998). Ou seja, ele deveria conhecer os "bons usos" do re- 
pertório discursivo e das representações teológico-políticas que poderiam ser aplicadas aos casos imprevistos nos discursos.

Tendo isso em vista, mesmo o malogro de uma ação pautada nas lições narradas em um discurso memorial não ocasionaria, necessariamente, a sua condenação por parte do corpo social, mas a abertura de outra expectativa em relação a ela, o que possibilitava o ajuste dessa mesma experiência e de sua relação causa-efeito às representações reconhecidas da organização social (GADAMER, 1998), e também a apropriação dessa experiência pelos modelos retóricos que normatizavam os discursos memoriais.

Isso acabava por diminuir a tensão existente entre os discursos memoriais e suas recíprocas intenções de legitimidade, pois essa atualização constante da experiência, tendo como base experiências anteriores "autorizadas" e já plasmadas na representação dos grupos político-sociais tendem, se não a impossibilitar, pelo menos, a dificultar a completa anulação de uma experiência anterior por outra mais recente.

Nessa perspectiva, ao analisar os discursos memoriais, devemos levar em consideração os mecanismos de avaliação que seus autores e público possuíam em relação às representações políticas, as quais diziam respeito ao conhecimento, sentimentos, e crenças compartilhadas acerca do ordenamento das esferas de poder e do papel exercido por cada um dentro delas, o que concorria para a formação de julgamentos e opiniões que as pessoas e grupos sociais nutriam em relação à organização político-social, e que se consolidavam em valores que orientavam a ação política (KUSHNIR; CARNEIRO, 1999).

As representações teológico-políticas apresentadas nos discursos memoriais referiam-se ao seu público receptor a partir da constituição hierárquica da sociedade, buscando persuadi-lo acerca da posição natural de cada um na ordem político-social. Para cumprir com tal objetivo, os discursos reproduziam padrões do modelo de ordenação político-social, que conformavam uma experiência coletiva partilhada assimetricamente, de acordo com o lugar social do autor, do homenageado e do público nas esferas de poder. No entanto, haja vista que somente se pode persuadir a respeito daquilo que se conhece, tais representações deveriam observar certas "regras de enunciação" (HANSEN, 2008), para construir e legitimar a memória exemplar pretendida.

\section{Considerações finais}

Nesse sentido, a análise das representações teológico-políticas nos discursos memoriais nos permite delinear determinadas configurações, concorrentes ou convergentes, utilizadas pelos diversos grupos sociais para representar e assimilar o modelo de ordenação político-social; as maneiras como tais representações e discursos reconheciam e demonstravam as identidades sociais; suas posições na hierarquia social; seus respectivos estatutos e, por fim, a forma como esses discursos e sua linguagem iam se institucionalizando, vincando e perpetuando a existência dos grupos e dignidades a partir dos seus representantes (CHARTIER, 1991). Dessa forma, as representações da ordem 
social contidas nos discursos extrapolavam o plano textual e adentravam no âmbito prático da ação política.

Portanto, os discursos não devem ser pensados fora de uma articulação com suas dimensões extratextuais ou de enunciação concreta. Torna-se necessário relacionar as representações retórico-políticas ao contexto histórico que condicionava sua produção e à "comunidade de discurso" que os produzia, ou seja, uma comunidade de autores que se utilizava de uma mesma linguagem e regras de enunciação para produzir e difundir discursos (POCOCK, 2003) que possuíam a mesma finalidade e unidade geral de sentido.

No caso dos discursos memoriais, a comunidade de discurso que os produzia era composta, majoritariamente, por religiosos e juristas que, ao possuírem autoridade atribuída pelo público receptor, tinham condições de desenvolver uma linguagem acerca do campo do político, organizando as regras de enunciação e determinando as possibilidades discursivas. Em contrapartida, essa elaboração do vocabulário político estava condicionada historicamente pela própria concepção de linguagem que se tinha nas monarquias ibéricas do século XVII (POCOCK, 2006). Para Hansen (2008), a linguagem seiscentista se configurava enquanto "jurisprudência" dos usos dos recursos linguísticos, que prescrevia que todas as representações retóricas deviam ser "boas", isto é, deveriam observar as regras de verossimilhança em relação ao objeto representado e de decoro em relação à ocasião hierárquica apresentada.

Dessa forma, estamos conscientes de que, ainda que durante a trajetória do home- nageado ocorressem experiências extraordinárias, cuja representação específica ainda não estivesse formalizada, os meios para fazê-lo já estavam dispostos nessa regra dos "usos autorizados dos signos", compartilhado pela comunidade de discurso e regulado por lógicas de analogia, que decidiam o verossímil e o harmônico entre os termos. No entanto, sabemos que cada nova experiência originada fora do discurso gerava novas dificuldades na linguagem utilizada para representá-la, ou seja, novas maneiras de utilizar o referencial que já se possuía (POCOCK, 2006).

As tentativas de legitimar experiências extraordinárias, ainda não reconhecidas e assimiladas pela ordem político-social, eram acompanhadas por um intenso debate dentro da comunidade de discurso, assim como a utilização de diversas estratégias discursivas por parte dos autores, tais como mudanças conceituais e inclusão de contextos emergentes (POCOCK, 2006). Dessa forma, as mudanças nos discursos devem ser observadas em conjunto com as tensões político-sociais que influenciavam a comunidade de discurso que os criava e difundia, e que transpareciam nos textos por meio das reutilizações de conceitos, metáforas, alegorias e demais elementos retóricos.

Contudo, é válido ressaltar que as convenções linguísticas utilizadas pela comunidade de discurso na elaboração dos discursos memoriais eram limitadas, primeiramente pela linguagem disponível a qual os autores podiam recorrer, e que era composta de lugares comuns adequados à cada ocasião e mensagem pretendida, isto é, "uma combinação de peças textuais na maioria das vezes 
preexistentes" (MASSIMI, 2005). Em segundo, pelos temas prescritos que condicionavam e direcionavam a discussão política, e em terceiro, pela própria condição do autor, que não pressupunha autonomia individual em relação aos critérios da comunidade de discurso, isto é, não possuía a prerrogativa de "subjetividade concorrencial", ou seja, os discursos memoriais não possuíam "originalidade", no sentido de "concorrer com outras originalidades no mercado de bens culturais" (HANSEN, 2008).

Ademais, há que se considerar que a linguagem se transforma a partir de pressões que lhe são externas. Consequentemente, o processo de resposta às novas experiências requer novos meios discursivos, ou novas maneiras de utilizar os meios já existentes. Todavia, esse processo demanda tempo e é marcado por diversas descontinuidades, especialmente no caso dos discursos memoriais, pois os autores encontravam-se em comunidades de discurso circuncidadas por paradigmas e convenções mais restritas acerca dos usos da linguagem (POCOCK, 2003).

Dentro dessa perspectiva, nos discursos memoriais coexistem dois níveis temporais de experiência, o sincrônico, que diz respeito a certas estruturas de repetição/atualização, como é o caso da memória, que se confirma pelos atos de rememoração; e o diacrônico, que se refere à singularidade das situações vividas pelo homenageado, narradas no discurso. Quanto mais autoridade é conferida à memória por parte dos agentes político-sociais, menos os acontecimentos únicos possuiriam a capacidade de romper as estruturas sincrônicas (KOSELLECK, 2006).
Portanto, em sociedades de cunho tradicionalista, tal como entendemos as monarquias da Península Ibérica no século XVII, nas quais a história e a memória se colocavam anteriormente a qualquer reflexão pragmática e, portanto, possuíam a autoridade de conferir sentido às práticas políticas; a dimensão diacrônica, isto é, aquela que diz respeito às experiências extraordinárias ou singulares, dificilmente prevalecia sobre a estrutura sincrônica, de caráter repetitivo.

De acordo com o que foi dito até agora, pode-se dizer que os discursos memoriais eram estruturados/formalizados por uma comunidade de discurso que se utilizava de uma espécie de linguagem política retórica, não institucional (como o é, por exemplo, a linguagem jurídica), com um modo de argumentação próprio, fundamentado na narrativa das experiências e virtudes de um grande homem, considerado como modelo de conduta a ser seguido por aqueles que exerciam a mesma função, ou outra semelhante, e também como exemplo moral à população em geral.

Por linguagem política, entendemos um conjunto de modos de enunciação conhecidas e reconhecidas por uma comunidade de discurso. Ou seja, uma linguagem política é um agrupamento de instrumentos e estratégias linguísticas possíveis, utilizadas por mais de um autor para se referir ao universo político de determinada época e localidade. Nesse sentido, a linguagem política não deve confundir-se com o estilo e subjetividade do autor, mas ser capaz de comunicar enunciados a diversos autores coetâneos (POCOCK, 2003). 
Esse modo de argumentação, típico das monarquias ibéricas do século XVII e dos discursos memoriais produzidos durante esse período, era reconhecido, utilizado e compartilhado por uma mesma comunidade de discurso (autores e autores-leitores), que compartilhavam uma linguagem política relacionada ao ideal de nobreza, para compreender-se entre si, e também para comunicar sua mensagem a uma comunidade interpretativa (POCOCK, 2003), a qual incluía tanto o público receptor, como os patrocinadores das obras. Por conseguinte, os discursos não eram demarcados somente pelas estratégias discursivas dos autores, mas também pelas simpatias e antipatias de sua audiência e de seus benfeitores, que embora não participassem da produção dos textos diretamente, delimitavam-nos de acordo com sua apreciação estética e categorias de compreensão do universo político.

\section{Abstract}

The present article intends to present a synthesis of theoretical-methodological reflections and research procedures regarding to the historical analysis of memorialist discourses, seeking to recognize and reconstruct its political dimension, as well as the rhetorical strategies used by the authors to confer an ideal representation of the political- social order, from which the public could recognize its social roles.

Keywords: Discourse Analysis. Iberian Monarchies. Representation of Power.

\section{Resumen}

El presente artículo pretende presentar una síntesis de reflexiones teórico-metodológicas y procedimientos de investigación en relación al análisis histórico de discursos memorialistas, buscando reconocer y reconstruir su dimensión política, así como las estrategias retóricas utilizadas por los autores para conferir una representación ideal del orden político- social, a partir de la cual su público receptor podría reconocer sus papeles sociales.

Palabras clave: Análisis del discurso. Monarquías Ibéricas. Representación del Poder.

\section{Nota}

1 Sebastião César de Meneses nasceu em Lisboa, em data incerta. Oriundo de uma família de grandes aristocratas, formou-se em teologia na Universidade de Coimbra. Foi comissário do Santo Ofício e ocupou diversos cargos na administração do reino, como membro do Conselho Régio, deputado do Conselho Geral do Santo Ofício, secretário de Estado de Nobreza, bispo-eleito de Porto, Bispo de Coimbra e Arcebispo de Braga. Em 1654 foi preso sob acusação de conspirar contra a Coroa, permanecendo no cárcere até a morte de Dom João IV. Após ser libertado, Sebastião César de Meneses tornou-se ministro do Rei Dom Afonso VI e Inquisidor Geral (ALBUQUERQUE, 1981). 


\section{Referências}

ALBUQUERQUE, Martim de. Para uma teoria política do Barroco em Portugal: A summa política de Sebastião César de Meneses (16491650). Revista de História, Porto, n. 4, p. 63-102, 1981.

ANDRADE, Francisco Eduardo de. A invenção das Minas Gerais: empresas, descobrimentos e entradas nos sertões do ouro da América portuguesa. Belo Horizonte: Autêntica/Editora PUC Minas, 2008.

CERDAN, Francis. La oración fúnebre del Siglo de Oro: Entre sermón evangélico y panegírico poético sobre fondo de teatro. Criticón, Tolouse, n. 30, p. 78-102, 1985.

CHARTIER, Roger. O mundo como representação. Estudos Avançados, São Paulo, v. 5, n. 11, p. 173-191, 1991.

FERREIRA, Valéria Maria Pena. Retórica das lágrimas: sermões e orações fúnebres na Bahia do século XVII. 2007. 260 f. Tese (Doutorado em Letras) - Faculdade de Letras, Universidade Federal de Minas Gerais, Belo Horizonte, 2007. p. 144-152.

FRANÇA, Susani Silveira Lemos. A representação do passado e a moral no século XV em Portugal. Tempo, Niterói, v. 14, n. 28, p. 145164, 2010.

GADAMER, Hans-Georg. Verdade e Método: traços fundamentais de uma hermenêutica filosófica. Tradução de Flávio Paulo Meurer. 2. ed. Petrópolis: Vozes, 1998.

HANSEN, João Adolfo. Barroco, neobarroco e outras ruínas. Destiempos, México, v. 14, n. 3, p. 169-215, 2008.

Instituição retórica, técnica retórica, discurso. Matraga, Rio de Janeiro, v. 20, n. 33, p. 11-46, 2013.
KOSELLECK, R. Futuro passado: contribuição à semântica dos tempos históricos. Tradução de Wilma Patrícia Maas e Carlos Almeida Pereira; revisão técnica de César Benjamin. Rio de Janeiro: Contraponto; Editora PUC-Rio, 2006.

KUSHNIR, Karina; CARNEIRO, Leandro Piquet. As dimensões subjetivas da política. Revista Estudos Históricos, v. 13, n. 24, p. 227-250, 1999.

LUZ, Guilherme Amaral. Produção da concórdia: a poética do poder na América portuguesa (sécs. XVI-XVIII). Varia Historia, Belo Horizonte, v. 23, n. 38, p. 543-560, 2007.

MARAVALL, J. A. A cultura do Barroco. Análise de uma estrutura histórica. São Paulo: Edusp, 1997.

MARTINS, William de Souza. O púlpito em defesa do Antigo Regime: a oratória franciscana na Corte joanina (1808-1821). Tempo, Niterói, v. 17, n. 31, p. 117-144, 2011.

MASSIMI, Marina. Palavras, almas e corpos no Brasil colonial. São Paulo: Loyola, 2005.

. Sermões Quaresmais e o conhecimento de si mesmo. Interações, Uberlândia, v. 11, n. 21, p. 97-120, 2006.

MENESES, Sebastião César de. Summa politica Offerecida ao Principe D. Theodosio nosso Senhor. Pelo bispo conde eleito Sebastião Cesar de Meneses. Impresso por ordem do Doutor João Pissarro Capellão de S. Magestade, Lisboa, por Antonio Alvarez Impressor DelRey N.S, 1649.

PERELMAN, C.; OLBRECHTS-TYTECA, L. Tratado da argumentação: a Nova Retórica. Tradução de Maria Ermantina Galvão. São Paulo: Martins Fontes, 1996.

PISSARRO Capellão de S. Magestade, Lisboa, por Antonio Alvarez Impressor DelRey N.S, 1649.

POCOCK, J. G. A. Linguagens do Ideário Político. São Paulo: Edusp, 2003. 
RAMÌREZ, Hugo Hernàn. Las relaciones fúnebres sobre la muerte de Carlos V. Calíope, Greensboro, v. 15, n. 1, p. 85-109, 2009.

SILVA, A. C. L. F. Reflexões metodológicas sobre a análise do discurso em perspectiva histórica: paternidade, maternidade, santidade e gênero. Cronos: Revista de História, Pedro Leopoldo, n. 6, p. 194-223, 2002.

URREJOLA, Bernarda. El panegírico y el problema de los gêneros en la retorica sacra del mundo hispanico: Acercamiento metodologico. Revista Chilena de Literatura, Santiago, n. 82, p. 219-247, 2012. 